\title{
New Horizons in the study of High Ability: Gifted and talented
}

\author{
María Dolores Prieto* y Mercedes Ferrando
}

Universidad de Murcia (Spain).

\begin{abstract}
Título: Nuevos Horizontes en el estudio de la Alta Habilidad: Superdotación y Talento.

Resumen: El siguiente trabajo sirve de introducción al número monográfico sobre superdotación y talento en la revista anales de psicología. En él se detalla el por qué de este número especial y se resumen las aportaciones de los distintos autores que tratan diversos temas. Desde la identificación, utilizando distintos procedimientos, la evaluación de la creatividad de dominio específico en ciencias, el estudio de la heterogeneidad de la población de altas habilidades, las medidas educativas de las que disponemos, y por último un estudio sobre las motivaciones académicas de estos alumnos. El trabajo concluye extrayendo unas conclusiones generales sobre lo que ha supuesto este monográfico y su aportación.

Palabras clave: Superdotación y Talento, investigación, Diversidad.
\end{abstract}

This monographic issue compiles different articles and experiences grounded on the principles of the Framework Program of the EU named Horizon 2020, which emphasizes that one of its principal objectives is tackling research in order to promote excellence. In this program, talented and creative people are provided with support, and such support is also given to work teams, so they can carry out high-quality, state-of-the-art research, based on success as a means to reinforce excellence, dynamism and creativity of the research conducted in Europe. All the works presented in this monographic issue are centered in the study of the exceptionally gifted and talented: individuals with an outstanding cognitive and non-cognitive potential.

It is a monographic whose goal is approaching giftedness and talent from different perspectives with a certain degree of consensus. It is agreed that giftedness is embodied in exceptional accomplishments, especially during adolescence and adulthood, whereas talent is reflected in remarkable achievements in specific commands (verbal, mathematical, scientific-creative, musical). Both types of excellence (giftedness and talent) are the result of the combination of biological, pedagogical, psychological and psycho-social factors.

The first work, titled "Challenges in the Identification of Giftedness: Issues related to psychological assessment" aims mainly for the implementation of a wider and more comprehensive system for the identification of highskilled students. In the last couple of years, different researchers and studies have not agreed about a single grading, intelligence test result or performance test as the means to study high ability (Renzulli \& Gaesser, 2015; Subotnik, Olszewski-Kubilius \& Worrell, 2011). In this regard, the article authors point at some recommendations for the identification of these students and the educational approach to their diversity. They draw attention, as well, to the lack of appro-

* Dirección para correspondencia [Correspondence address]: María Dolores Prieto. Facultad de Educación, Universidad de Murcia, Campus de Espinardo. 30100. Murcia (Spain).

E-mail: lola@um.es
Abstract: The following piece of work serve as introduction to the monographic issue about giftedness and talented in the Annals of Psychology Journal. In it, the reasons to tackle this monographic are explained, and the contributions of authors are summarized. such contributions are diverse and swing from the identification process using different procedures, the assessment of domain specific creativity in sciences, the study of the heterogeneity within the group of high ability students, the educational measures available, and lastly and study about these students' academic motivations. The work concludes extracting some general conclusions about what this monographic has contribute and it's meaning.

Keywords: Giftedness and talent, research, Diversity. priate instruments to value their excellence. Furthermore, they note that any identification test should meet standards of validity and reliability, so they can distinguish high-skilled students from their peers.

In the process of identification, not only the students, but also their parents and teachers must participate. In said process, on the one hand, the singularities of cognitive skills (attention, perception, working memory, concept formation, reasoning, problem-solving, cognitive styles and metacognition) should be considered for the impact they have on the teaching-learning process; on the other hand, the functioning of non-cognitive aspects (motivation, persistence, self-image, anxiety management and perfectionism) and personality traits (self-determination, conscience and opening to experience) are considered too, for the impact they have on academic performance and on personal and social accomplishments.

It is from these new approaches on the study of high ability when the combination of personal aspects along with environmental factors is introduced. Ultimately, the authors propose that, in the process of identification, different procedures which include various sources of information and instruments adapted to the culture and linguistic competence of these individuals need to be utilized. All of this, because giftedness and talent, as pointed out by Subotnik et al. (2011), reflect the values of a society, are manifested in the shape of outstanding, real achievements in specific commands and are the result of the coalescence of biological, pedagogical, psychological and psycho-social factors related, not only to the "normal" (for instance, a child with an exceptional technical ability if compared to his/her parents), but to the "extraordinary" (for example, an artist who revolutionizes the field of technology).

The second work, named "Multidimensional Assessment of Giftedness: Criterion Validity of Battery of Intelligence and Creativity Measures in Predicting Arts and Academic Talents" intends to value the usefulness of a battery to identify high-skilled students. The battery has 
been used so as to determine the differences between 2 groups of students: academically and artistically talented. The battery assesses four of the defining components of high ability: reasoning or fluid intelligence, divergent production of metaphors (both verbal and creative), divergent-figurative thinking (figurative fluency) and quality of the responses of the creative-figurative fluency. The study was carried out with 987 individuals (464 boys and 523 girls, aged between 8 and 17 years old). Among these individuals, the tests showed that 866 of them did not present high ability, 67 were academically talented, 34 artistically talented and 20 presented no talent whatsoever. The results showed that academic talents featured higher scores in processes of reasoning, produce a greater number of metaphors; they also feature higher figurative fluency and greater figurative originality. With regard to the differences between academic and artistic talents, the data reveal that the processes of reasoning are superior among the group of academically talented in comparison to the artistically talented. The academically talented show higher levels of reasoning (verbal, abstract, logical and numerical) as well as greater production of creative metaphors, whereas the artistically talented obtain higher scoring in those tasks demanding figurative creativity; this data reveals the interaction between the type of creativity and type of talent. Within the group of artistically talented, it can be observed that their reasoning capacity is less important than their figurative fluency and originality. This work is in line with recent studies which highlight the important of assessing the creativity in different commands along with intelligence, since it allows us to understand better the complexity of high ability (Lubart, \& Zenasni, 2010; Lubart, Besançon, \& Barbot, 2011).

The third research about the Identification of Verbal and Mathematical Talent: results of the application of the Talent Search Model in Spain has two objectives: firstly, to present the Talent Search Model as an identification model oriented towards the annual selection of a great number of students with both mathematical and verbal talents, considered the backbone of all school learning. The first Talent Search was carried out by Julian Stanley en 1972 and the constant research resulting from said model has given rise to the creation of a nationwide structure in the US that offers support to high skilled children in each state Stanley, 1976, 1996). Such support has been materialized in educational programs and services for parents and for talented children. The second objective is to present the data after several years of application of the model in Spain, a model which can be labeled a universal one, grounded on the principle of measuring. The data allow us to see the variability and heterogeneity of the talents above the level (above or out of leve). Some suggestions for the implementation in schools of this procedure on a large scale are offered. The authors conclude that "high ability" is not limited naturally to this academic dimension, nor does the model intend to suggest such a thing (Stanley, Keating, \& Fox, 1974).
What the model does want to highlight is the deliberate practice necessary to eventually become talent (competence) in the different fields of human activity. Therefore, having systematic mechanisms, easy to implement at a large scale is of paramount importance. The Talent Search Model is, by no means, an exclusively American model, since as it has been proven; its principles are cross-cultural (Tourón \& Tourón, 2011).

The fourth work, titled $\boldsymbol{A}$ New Measurement of Scientific Creativity: The Study of its Psychometric Properties seeks to offer a new instrument of evaluation scientific creativity and deepen in the study of scientific-creative talent. This test measures scientific creativity, assessed by means of the fluency, flexibility and the creativity quotient in different areas of knowledge (biology, chemistry, physics and interdisciplinary of the rest of areas of science). A research in which 344 students of compulsory secondary education have participated is presented. The results revealed a high reliability ( $a$ $=.705$ ) as well as a reasonable inter-judge agreement (varying the average ICC from .80 to .98). It is also been verified by means of the AFC the uni-factorial structure of the test, according to the authors' proposal (Ayas \& Sak, 2014; Sak \& Ayas, 2013), but deeming the structure of three creative processes composed of different tasks each one, a feasible one. The innovative nature of this work lies in the fact that it presents a valid instrument so as to evaluate the potential of scientific-creative talent, which allows us to set attention to diversity standards adjusted to their profile.

The fifth work, Gifted and talented children: Heterogeneity and individual differences is aimed at studying the variability between high-skilled students. To prove such heterogeneity and the individual differences with respect to the students' analytical skills, the authors carried out two studies: first, the level of cognitive ability is estimated by means of the latest version of the Wechsler Intelligence Scales for Children (Wechsler, 2005). In this study, 99 children (with ages between 6-16, average age $=9$ years and 5 months). The data reveal that there is much more variability between the high-skilled students than their peers (non-gifted). In the second work, the individual differences and heterogeneity between the musically talented are studied. 84 students (aged $6-18$, average age $=11$ years and 6 months) participated. These students took part in a variety of educative activities (private lessons, private music schools and music academies), where they play different musical instruments (piano, wind, string and percussion). The results reveal 2 profiles: 1) the profile "Obligation": the child took up a musical activity, not voluntarily; their parents choose the instrument for him/her. Different people within the family have carried out a given artistic activity (no matter which); parents are highly involved in the child's musical training. The child has no autonomy; the training sessions have an average length of half an hour; parents attend the lessons, and the child perceives such activity as an "obligation". 2) The profile known as "Passion": the child got into music for a variety of reasons and by mutual agreement with their family and background. The child 
chooses the instrument. Some member of the family may (or may not) perform an artistic activity. Parents are not actively involved in the child's training; the child is autonomous, works in sessions that, on average, last more than one hour and actually perceives and lives music as a "passion". In this regard, the talented feature more often the profile "passion" than "obligation". In synthesis, the authors claim that the principal finding is the heterogeneity among the children with high potential. Giftedness, when turned into talent, is manifested more frequently in one command (such as verbal ones, mathematics or arts).

The sixth article, titled "Intelligence and Giftedness: An empirical study" seeks to study the different types of high ability (giftedness and talent) so as to offer an educational response to the diversity of this kind of students. There are scarce empirical works which aim at identifying the profiles of giftedness and talent beyond the theoretical level. The present work intends to identify patterns of combination of the abilities inherent to the triarchic intelligence (analytical, synthetic-creative and practical) as defined by Sternberg in the field of high ability. A total of 431 boys and girls from different schools in the Region of Murcia have taken part in the study. An Aurora Battery (Chart, Grigorenko \& Sternberg, 2008) has been used to assess the abilities of the three types of intelligence. While conventional standardized tests evaluate a big part of the abilities necessary to have a successful performance at school, this new approach allows to value the talent potential by means of tests which measure analytical abilities (necessary at school), creative abilities, so as to deal with the solutions to problems which demand original responses valued by the society and by experts, and practical abilities, in order to convince people of the value of different ideas and carry these out (Sternberg, 2015). The data reveal different profiles resulting from the combination of analytical, synthetic-creative and practical abilities. Profiles which prove right the theory put forward by Sternberg (2000): analytical talent, practical, creative, analytical-practical, analytical-creative profile, practical-creative and consummate balancer profile. As a conclusion, the authors highlight, on the one hand, the importance of assessing these types of skills in the study of high skills, since utilizing this type of tasks allows to know how students handle their creative mechanisms (the capacity of producing new, original and non-conventional ideas), the analytical (capacity of analyzing and evaluating if said ideas work) and the practical ones (the capacity to put those ideas into practice and to convince people of their value). On the other hand, the results show the different ways talent can be materialized, and this allows design educational responses appropriate to the heterogeneity and diversity of the profiles of high ability.

The seventh work, named "Educational Programs for Talented Students (EPTS)" intends to present a curricular model to cater to the diversity of the students with mathematic and scientific talent. This model has two dimensions: abilities and content. The abilities (analytical, creative and practical) have a hierarchic structure with three levels of pro- foundness. The program includes the abilities previously stated in Sternberg's theory of successful intelligence (1997) and is grounded on the principles of teaching of successful intelligence (Sternberg \& Grigorenko, 2003). This hierarchy of abilities is interesting, for it enables to work on them according to the complexity and level of abstraction that the diversity and heterogeneity of the talented requires. In the content, the standard knowledge depending on the level along with the handling of abstract ideas and the generalization of principles and theories stemming from the contents are included. It is an extracurricular program offered at weekends and summers. This format of program is one of the best options for certain educational systems, such as the Turkish one, which lacks the sufficient flexibility for the acceleration or other systematic measures. The virtues of this program (EPTS) can be summarized in the following points: is a system of evaluation of abilities of a specific command; for such evaluation multiple criteria are employed, it can be used to identify mathematical and scientific talent. It is precisely the assessment of the handling of specific knowledge which allows detecting strengths and weaknesses, something that requires adapting and clarifying for the sake of an optimal educational response. This model supposes an adequate proposal of attention to the diversity of talent and combines two measures of educational response: enrichment and acceleration. The results coming from the different studies carried out with this program show that it is efficient in the attention to talents. It is a program aimed at achieving excellence, especially in the mathematic and scientific talents.

Finally, the eighth study entitled "Motivational Orientations of High-Achieving Students as Mediators of a Positive Perception of a High-Achieving Classmate: Results from a Cross-national Study" aims to explore the prejudices and social perception of high achiever students from the point of view of other high achievers. The authors hypothesized that peers perception may be mediated by the eye holder's learning goals and motivations. It is interesting to think whether high achievers will perceive a similar classmate with skepticism or if this student is rather seen as a potential model that confirms the adequacy of their own achievement behavior. In this study a total of 1794 students from six different countries (Australia, Peru, South Korea, Spain, and Vietnam) took part. Of them, 396 were identified as high achievers. Students answered a questionnaire referred to Perceptions of high-achiever attributes and another questionnaire to identify their learning goals approach. The results of the study indicated that High achieving students in all countries participating in the study ascribe to a new highachieving student's positive attributes such as high intellectual abilities and social qualities. This result is extensible in the six participating countries. Being this a cross-cultural finding, about perception of the own qualities of high achieving students.

Some of the conclusions of the Monographic issue can be summarized in the following points: 
There is a great degree of heterogeneity among the exceptionally-gifted and talented students. It is not possible for any school program to fully attend to all the needs of talented students. Those developing school programs should be encouraged to adapt to the individual differences between students by means of the extracurricular flexibility.

Students endowed with mathematical and scientific talent need to interact with their "intellectually equals": the fact of being in company of their intellectual peers allows them to grow socially and emotionally as well as to share common interests.

\section{References}

Ayas, M. B., \& Sak, U. (2014). Objective measure of scientific creativity: Psychometric validity of the Creative Scientific Ability Test. Thinking Skills and Creativity, 13, 195-205.

Chart, H., Grigorenko, E.L., \& Sternberg, R.J. (2008). Identification: The Aurora Battery. J.A. Plucker \& C.M. Callahan (Eds.), Critical issues and practices in gifted education (pp. 281-301). Waco, TX: Prufrock.

Lubart, T.I. \& Zenasni, F. (2010). A new look at creative giftedness. Gifted and Talented International, 25(1), 53-57.

Lubart, T.I., Besançon, M., \& Barbot, B. (2011). Evaluation du Potentiel Créatif (EPoC). (Test psychologique et Manuel). Paris: Editions Hogrefe France.

Renzulli, J. S., \& Gaesser, A. H. (2015). Un sistema multicriterial para la identificación del alumnado de alto rendimiento y de alta capacidad creativo-productiva. Revista de Educación, 368, 96-131.

Sak, U., \& Ayas, M. B. (2013). Creative Scientific Ability Test (C-SAT): A new measure of scientific creativity. Psychological Test and Assessment Modeling, 55(3), 315-328

Stanley, J. C. (1996). SMPY in the beginning. In C. P. Benbow \& D. Lubinski (Eds.), Intellectual talent: Psychometric and social issues (pp. 225-235). Baltimore, MD: Johns Hopkins University Press.

Stanley, J. C. (1976). Special fast-mathematics classes taught by college pro-
It is necessary to carry out a description of the different profiles of capacities among students, their interests, their strengths and weaknesses, their degree of talent, something which will demand varied educational planning. It has been mentioned above that talents varies enormously, even in carefully selected groups. Likewise, it will be necessary to adapt the educational response, taking into consideration not whether or not a student has a talent or ability above the average at a given level, but how above the average of that level he/she is. In other words, how exceptional their capacity is.

fessors to fourth- through twelfth-graders. In D.P. Keating (ed.), Intellectual talent: Research and development (pp. 132-159). Baltimore: The Johns Hopkins University Press.

Stanley, J.C., Keating, D., \& Fox, L. (1974). Mathematical talent: Discovery, description, and development ( $p$ p. 101-125). Baltimore: The Johns Hopkins University Press.

Sternberg, R. J. (2000). Patterns of giftedness: A triarchic analysis. Roeper Review, 22(4), 231-235.

Sternberg, R. J. (2015). Successful Intelligence: A model for testing Intelligence beyond IQ tests. European Journal of Educational Psychology, 8, 76-84.

Subotnik, R. F., Olszewski-Kubilius, P., \& Worrell, F. C. (2011). Rethinking giftedness and gifted education: A proposed direction forward based on psychological science. Psychological Science in the Public Interest, 12, 3-54.

Tourón, J. \& Tourón, M. (2011). The Center for Talented Youth Identification Model: A Review of the Literature. Talent Development \& Excellence, 3(2), 187-202.

Wechsler, D. (2005). Manuel d'administration et de cotation du WISC-IV. Paris: Editions du Centre de Psychologie Appliquée.

(Article received: 20-03-2016; revised: 28-03-2016; accepted: 06-04-2016) 